\title{
Geotechnical Investigations on Highway BR 135 for Earthworks, Asphalt Paving and Special Art Works in Subsection Municipalities Manga-Itacarambi, North of Minas Gerais
}

\author{
Rideci Farias $^{1(\bowtie)}$, Haroldo Paranhos ${ }^{1}$, José Jailson Nogueira ${ }^{2}$, \\ Marco Aurélio Diana Costa ${ }^{3}$, and Roberto de Pimentel Sousa Junior ${ }^{4}$ \\ ${ }^{1}$ UCB/Reforsolo Engenharia/UniCEUB/IesPlan, Brasília, Brazil \\ rideci.reforsolo@gmail.com, reforsolo@gmail.com \\ 2 VALEC, Brasília, Brazil \\ jailson.np@gmail.com \\ ${ }^{3}$ UniCEUB, Brasília, Brazil \\ marco_aurelio_d@hotmail.com \\ ${ }^{4}$ UCB/UNB, Brasília, Brazil \\ eng.robertopimentel@gmail.com
}

\begin{abstract}
This article presents part of the results and discussions of the geotechnical studies carried out in the area and in materials collected in the BR 135 in the section between the counties of Manga and Itacarambi in the state of Minas Gerais. The study consisted in the execution of field work and laboratory work. In the field investigations were performed (auger, SPT and rotary), collecting material (soil and rock), densities "in situ" and identification/tactile-visual classification of materials. In the laboratory, with soils and rocks collected, were performed additional tests necessary to the design and implementation of the road in question, in that stretch. The studies focused along the existing highway axis and the track side, and side guidance in the predicted contours, concentrated deposits of soil, deposits concentrated of gravel, sands deposits and deposits of rocky material. With implementation of Auger investigations, it was found that the soils tactile-visual characteristics are similar to the predominance of yellow/red sandy soils. It was found that along the highway there are competent rocky material and also friable, mixed, which are not local, but come from deposits in the region and which were used in the primary coating of the road. In the carrying out field work, was done a broad recognition of the BR 135 insertion region that recognition was found that the region is covered by a wide layer of typical sandy soil (Red and Yellow Latosol). In the case of rocky material, it was found that there is a high occurrence of carbonate rocks in the region. This rock is exploited and used as building material, especially on pavements and as aggregates for concrete (Gravel 1, 2 and Gravel Gravel powder). Being a characteristic rock materials in the region, it was used for granulometric tests of sand equivalency, organic matter content, form of content, durability, abrasion "Los Angeles" and adhesiveness. The check of sands deposits, local people reported that most of the sand used in the region comes from dredging the San Francisco River in the
\end{abstract}


municipality of Itacarambi. two locations sands were also collected in the municipality of Mango, also the banks of the São Francisco River.

Keywords: Geotechnical investigation $\cdot$ BR $135 \cdot$ Manga $\cdot$ Itacarambi

\section{Introduction}

This article aims to present some of the results of the geotechnical studies carried out in the area and collected materials on the BR 135 in the stretch between the towns of Manga and Itacarambi in the State of Minas Gerais. The studies consisted in performing field work and laboratory. On the field were executed investigations (Auger, SPT and rotating), collecting material (soil and rock), in situ density and identification/classification of materials. In the lab were carried out further testing required for the design and implementation of the road between the municipalities Manga and Itacarambi, State of Minas Gerais.

The studies were concentrated along the existing axis and in the sides of the highway to be paved in the guideline and sides of the contours to be executed, concentrated deposits of soil, concentrated deposits of gravel, sand deposits and deposits of stonelike material.

The field work was conducted in the months of June, July and November, and the laboratory work were executed in the months of July, August, November and December 2010.

The field studies were reconciled with the Office so that the information they were consistent with the topographic study provided.

With the implementation of the Auger investigation, it was found that the tactile-visual characteristics soils similar to the predominance of yellow/red sandy soils.

\section{Location Studies of Execution Area}

The area of execution of study is located between the municipalities of Manga and Itacarambi in the state of Minas Gerais. In terms of organization, the area was divided into four sections, and was classified as follows:

Stretch 1: Segment between the municipalities of Manga and São João das Missões;

Stretch 2: Segment between the City of São João das Missões to the start of paved stretch, passing for the small city called Rancharia;

Stretch 3: Manga municipality contour;

Stretch 4: Outline of the City of São João das Missões;

Figures 1 and 2, from Google Earth, show the insertion area of the enterprise in question. 


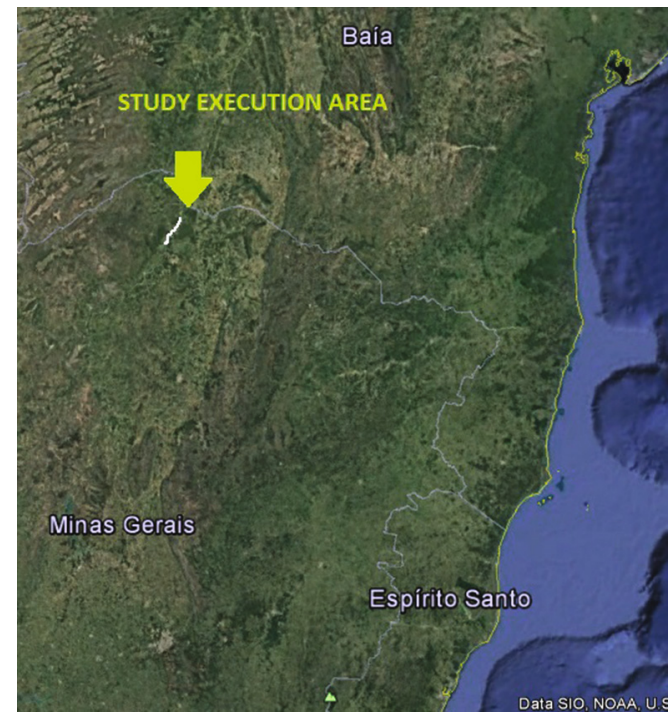

Fig. 1. Macro view of the studies area

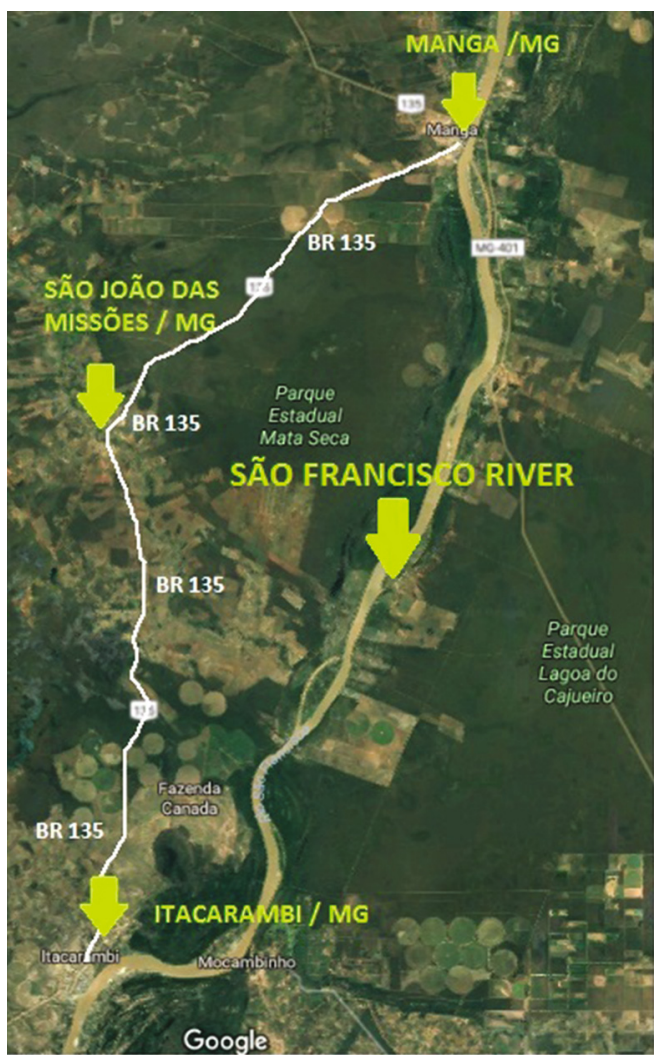

Fig. 2. Macro view of studies running area (Excerpt: Manga - Itacarambi). 
Figures 3 and 4, also from Google Earth, present, respectively, the outlines provided in the municipalities of Manga, and São João da Missões.

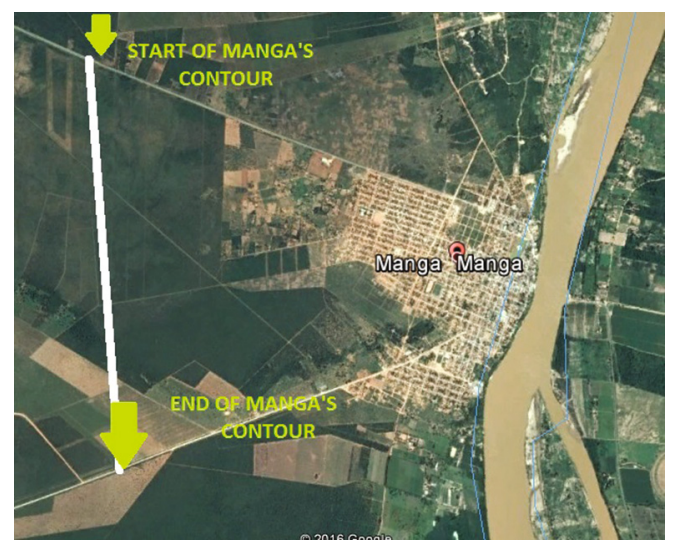

Fig. 3. View contouring Manga/MG. Home (approximate coordinates: Start $14^{\circ} 44^{\prime} 04.6^{\prime \prime} \mathrm{S}$,

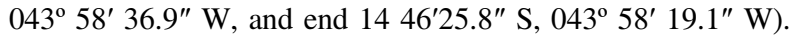

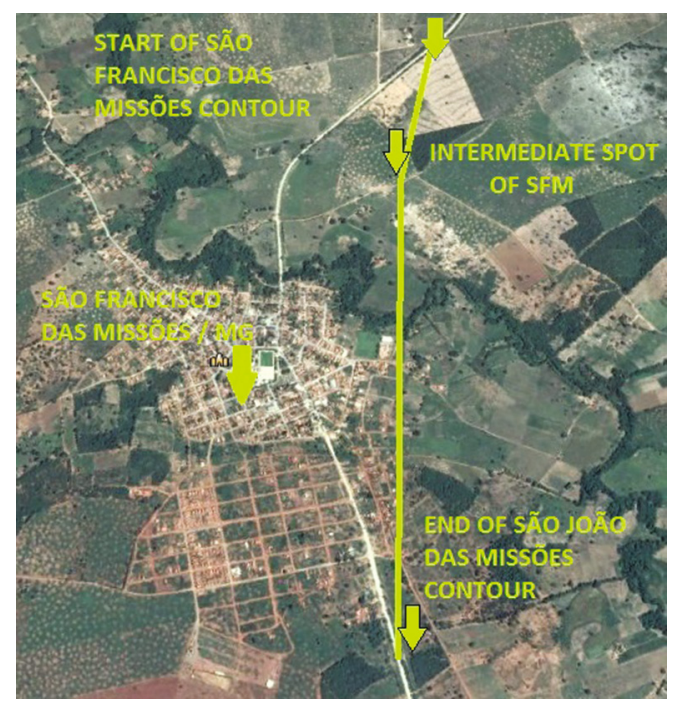

Fig. 4. View the outline of St. John of the Missions. Home (approximate coordinates: Home $14^{\circ}$ $52^{\prime} 15,875^{\prime \prime} \mathrm{S}, 044^{\circ} 04^{\prime} 44,751^{\prime \prime} \mathrm{W}$, and end 14 53'20.6" S, 044 $04^{\circ} 39.3^{\prime \prime} \mathrm{W}$ ).

\section{General on the Region of Materials}

In carrying out of field work was done a detailed recognition of the region of insertion of BR 135. In recognition was found that the region is covered by a wide layer of typical sandy soil (Red Latosol and Yellow Latosol), Figs. 5 and 6. Along the track 


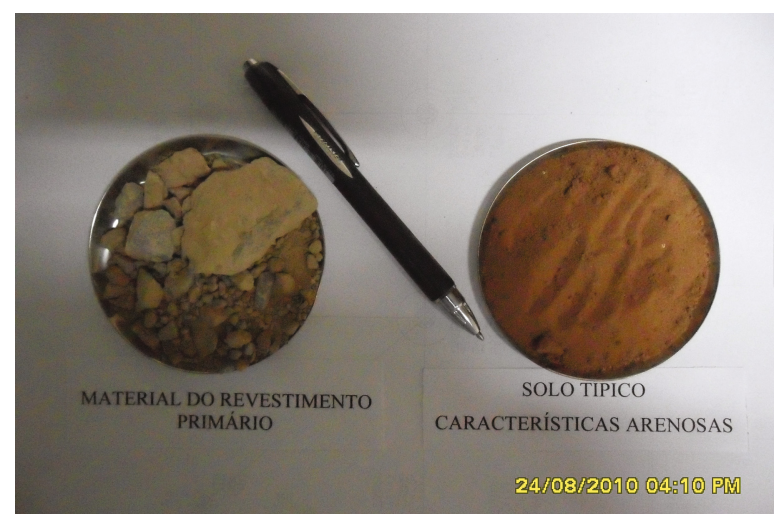

Fig. 5. Material of the primer coating and typical sandy soil found in the region.

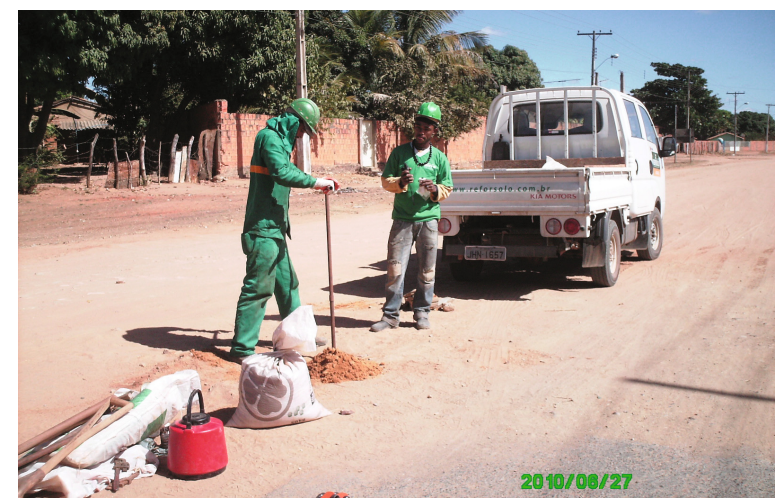

Fig. 6. Start of Manga-São João das missões. Also observe the implementation of the survey auger.

axis and contours, has the typical profile shown in Figs. 7, 8, 9 and 10. Samples of the surface layers of these profiles were collected but not used in the implementation of laboratory tests. For soil concentrated study, we used an area near the municipality of São João da Missões.

In the case of rocky material, it was found that there is a high occurrence of carbonate rocks in the region. This material is exploited and used as building material, especially on pavements and as aggregates for concrete (Gravel 1, 2 and Gravel powder). 


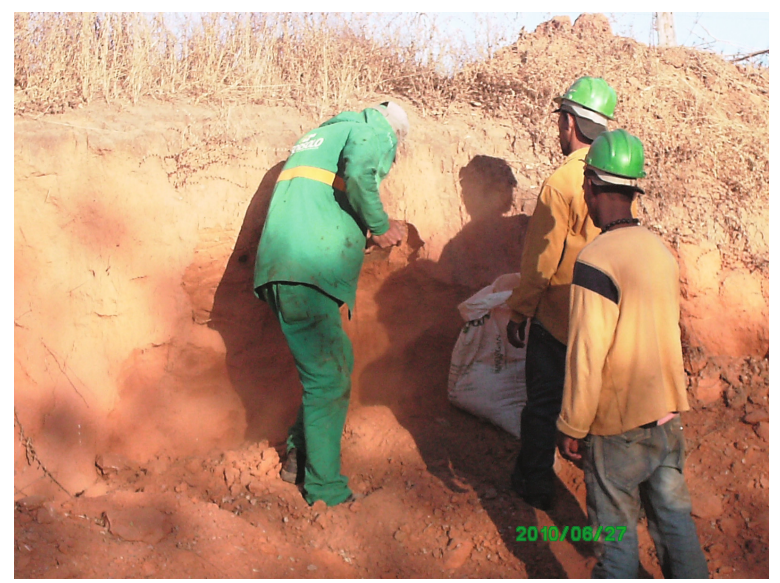

Fig. 7. Typical via banks. Manga-São João das Missões. (GPS $14^{\circ} 50^{\prime} 28.6^{\prime \prime} \mathrm{S}, 44^{\circ} 03^{\prime} 12^{\prime \prime} \mathrm{W}$ )

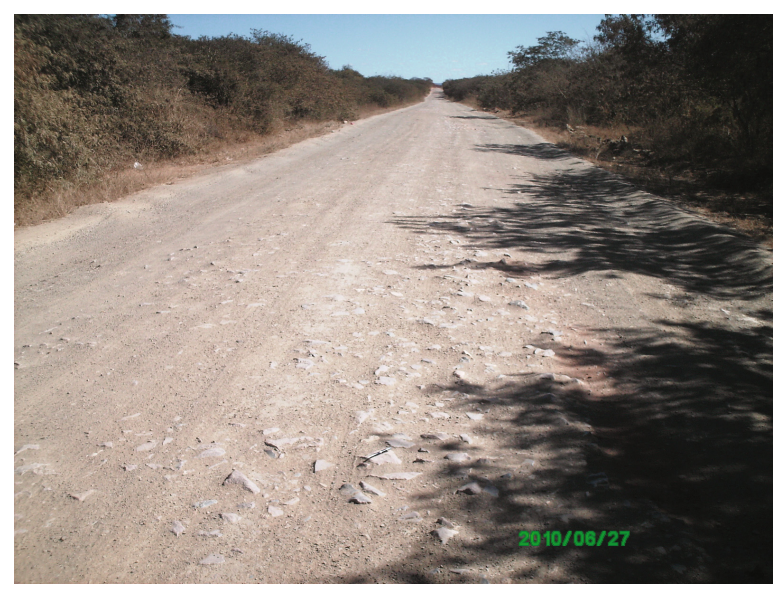

Fig. 8. Excerpt from Manga-São João das Missões. Observe typical rocky material in the surface layer.

Note: It is verified that along the way there is the existence of competent rocky material and also friable, mixed, which are not local, but come from deposits in the region and which were used in the primary coating of the road.

Aiming the possible deployment of a bridge on the outline provided in São João das 


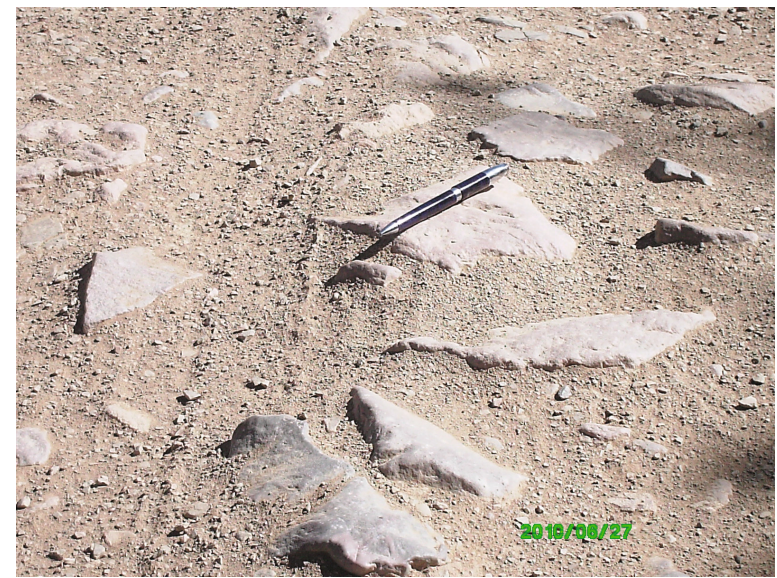

Fig. 9. Excerpt from Manga-São João das Missões. Detail of the typical rocky material in the surface layer.

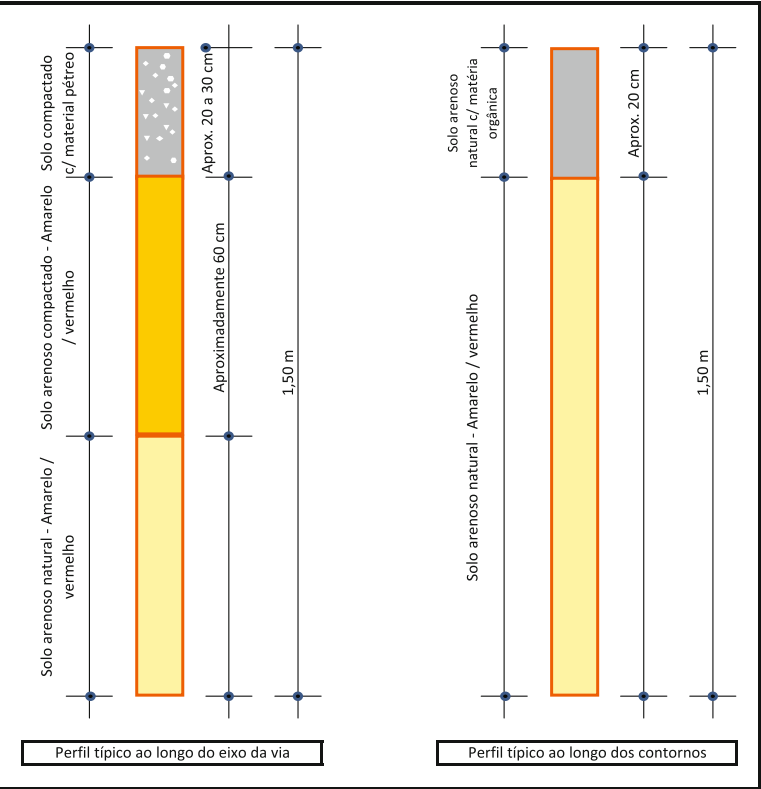

Fig. 10. Typical profiles prevailing in the local collection of soil samples

Missions, mixed investigations were performed (SPT + Rotating), Figs. 11 and 12. 


\section{Results of Studies Performed}

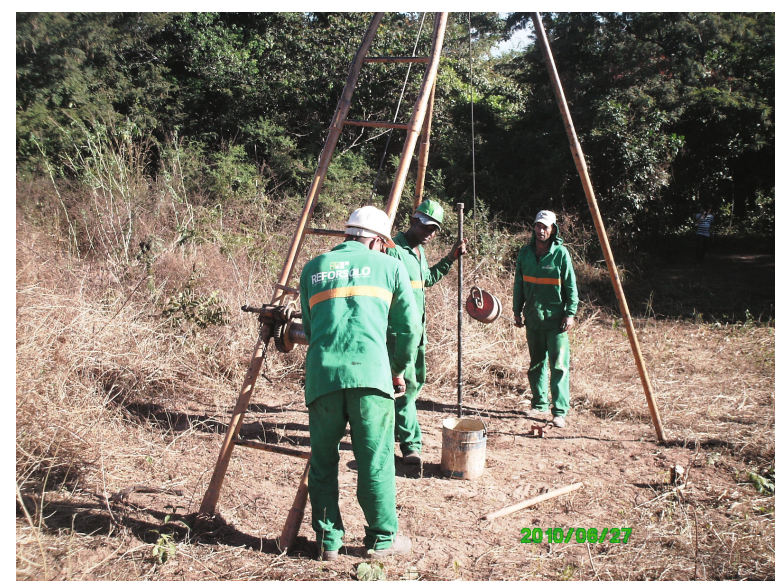

Fig. 11. Implementation of the SPT survey on the river Itacarambi possible to bridge the implementation outline of São Joao Mission.

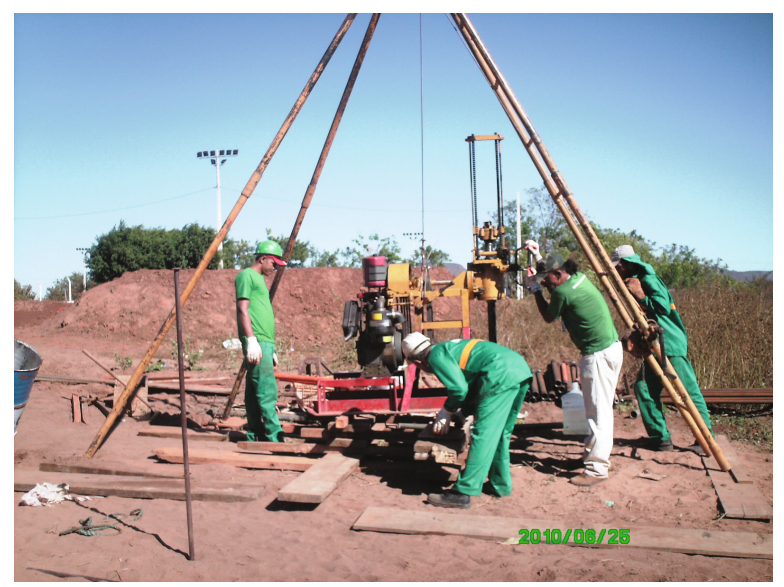

Fig. 12. Execution of the rotary drilling on the river Itacarambi possible to bridge the implementation outline of São Joao Mission.

As already mentioned, the study consisted in the execution of field work and laboratory. In the field site investigations were performed (auger and rotary SPT), collecting material (soil and rock), densities "in situ" and identification/material classification. In the laboratory, with soils and rocks collected, the following tests were performed: (a) moisture content; (b) Liquidity Limits and Plasticity; (c) Granulometri by sieving and sedimentation, using as a dispersant sodium hexametaphosphate; (d) real density of 
soil grains; (e) compression; (f) California Support Index (ISC or CBR); (g) content of organic matter; (h) Sand Equivalency; (i) Abrasion "Los Angeles"; (j) Adhesion; (k) Durability; (l) index of form; (m) Material Classification; (n) Analysis of SPT; (o) Analysis of Rotating SPT. The following part summaries are presented the results of studies performed.

\subsection{Soil Collected in Axis of Projected via}

Figure 13 shows a summary of the average of the physical and mechanical characteristics of the soil along the Via to be paved. Through this figure, has the follow results: in granulometric terms the predominant soil is sandy; not liquid and not plastic; Sand equivalency equal to 33\%; Group Index equal to zero; The predominant soil-2-4

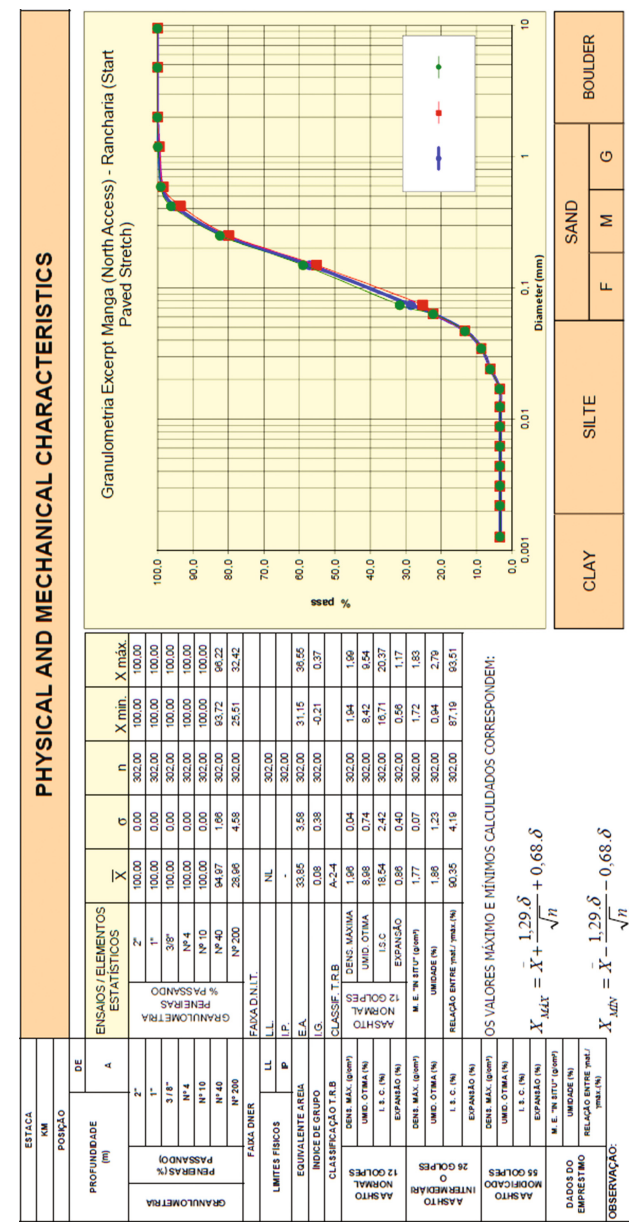

Fig. 13. Summary and physical characteristics and soil mechanics for kids stretch (North) 
(gravel or silty or clayey sands) the classification TRB (HRB); optimum moisture content in the normal energy equal to $8 \%$; ISC (CBR) 18\%; Expansion of the compacted material after $96 \mathrm{~h}$ of immersion of $0.86 \%$; apparent density of $1,77 \mathrm{~g} / \mathrm{cm}^{3}$; natural moisture of $1.86 \%$.

\subsection{Deposits of Soil and Gravel}

For areas of lending materials, we studied a concentrated deposit of soil and three deposits of gravel. The field soil has similar characteristics to that shown in Fig. 13. The soil collected in this field was also used to study soil-gravel mixture. Two Soil Gravel mixtures were studied. A mixture of $20 \%$ and another $30 \%$ Gravel, being respectively $80 \%$ and $70 \%$ of soil. Figures 14 and 15 show the results obtained for these mixtures (soil and gravel). In the case of compression it is found that the normal

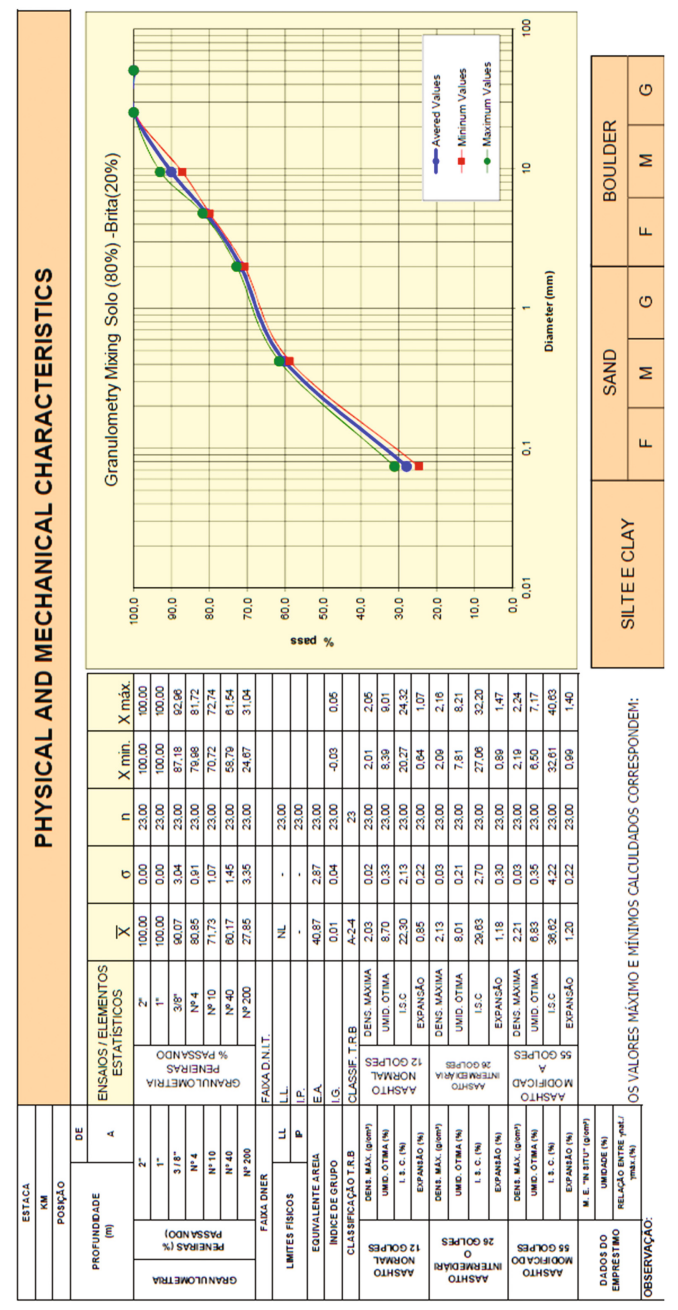

Fig. 14. Study summary for soil mix (80\%) - Gravel (20\%). 


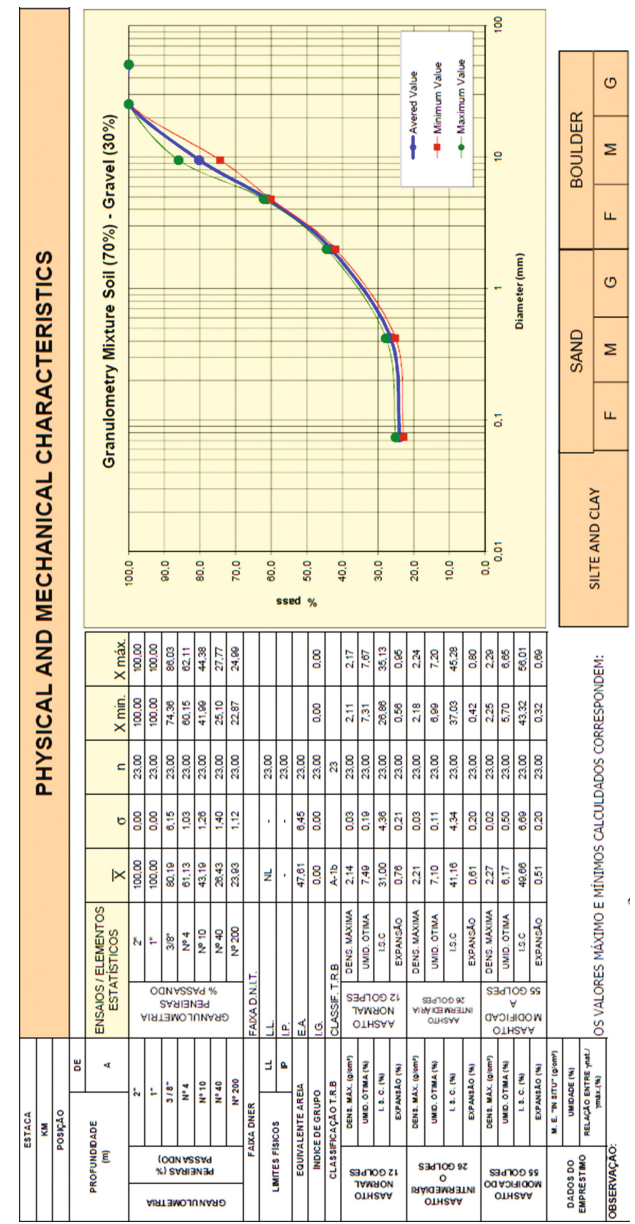

Fig. 15. Study summary for soil mix (70\%) - Gravel (30\%).

power sample with $20 \%$ dry gravel has optimum moisture content and density, respectively $2,03 \mathrm{~g} / \mathrm{cm}^{3}$ and $8.70 \%$. Already $30 \%$ of crushed stone features $2.14 \mathrm{~g} / \mathrm{cm}^{3}$ and $7.49 \%$ of optimum moisture.

Next, in Fig. 16, is shows one of the gravel deposits studied, and Fig. 17 presents a summary of this study for this deposit. It is observed that in terms of compacting the material has medium for optimum moisture content and maximum dry density in normal power $\left(13.2 \% ; 1.90 \mathrm{~g} / \mathrm{cm}^{3}\right)$, intermediate $\left(12.7 \% ; 1.96 \mathrm{~g} / \mathrm{cm}^{3}\right)$ and modified $\left(12.0 \% ; 2.01 \mathrm{~g} / \mathrm{cm}^{3}\right)$. 


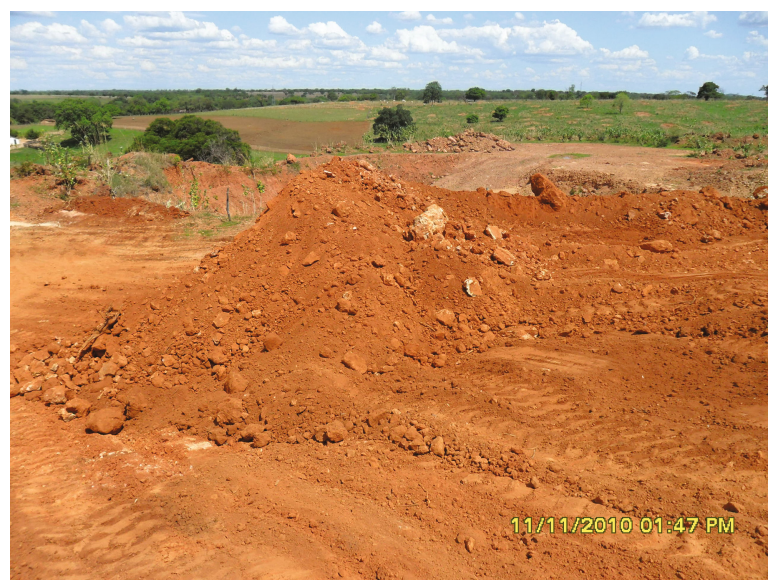

Fig. 16. View of the gravel deposits studied.

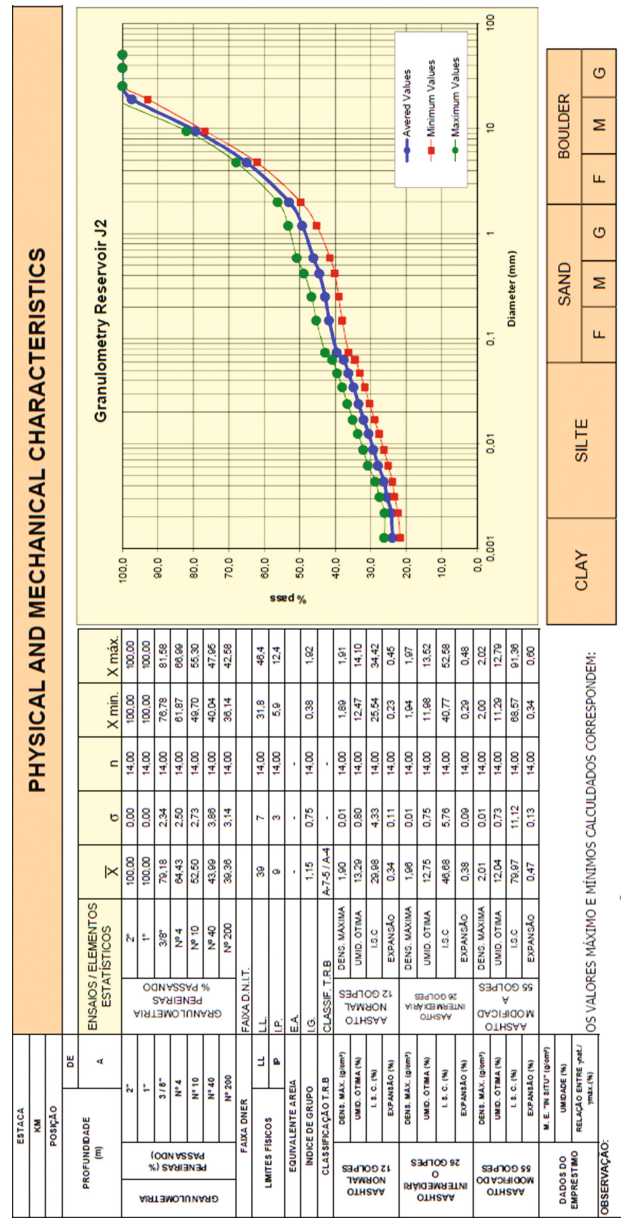

Fig. 17. Study summary for the gravel mine. 


\subsection{Sands Deposits}

During the check of sands deposits, local people reported that most of the sand used in the region comes from the dredging of the river San Francisco in the municipality of Itacarambi. On the way to the site (Fig. 18) and in conversations, it was found that are marketed three kinds of sand called by traders "fine sand", "pebble" and "sand with pebble", as shown in Fig. 19. In addition to these in two locations, sands were collected in Manga municipality, also in the margins of the São Francisco river.

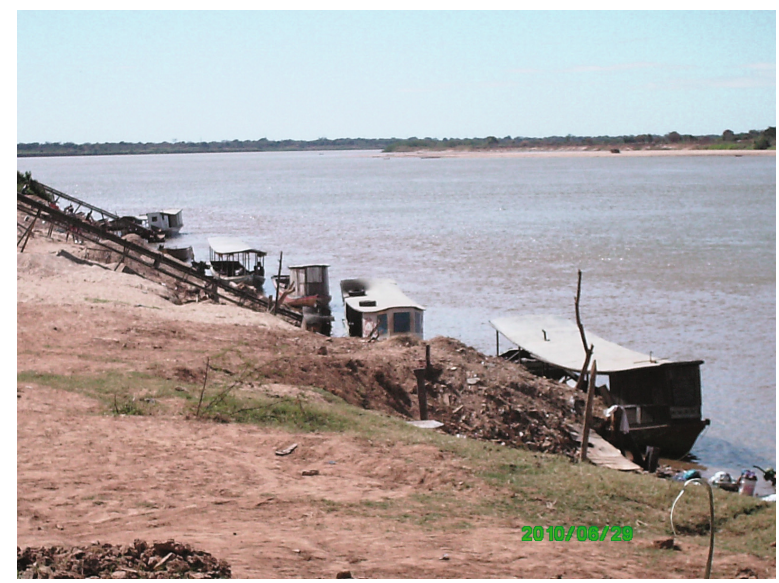

Fig. 18. Sand dredgers area view in Itacarambi/MG on the banks of the São Francisco River (GPS 15 $06^{\prime} 18.7^{\prime \prime} \mathrm{S}, 44^{\circ} 05^{\prime} 41.1^{\prime \prime} \mathrm{W}$ ).

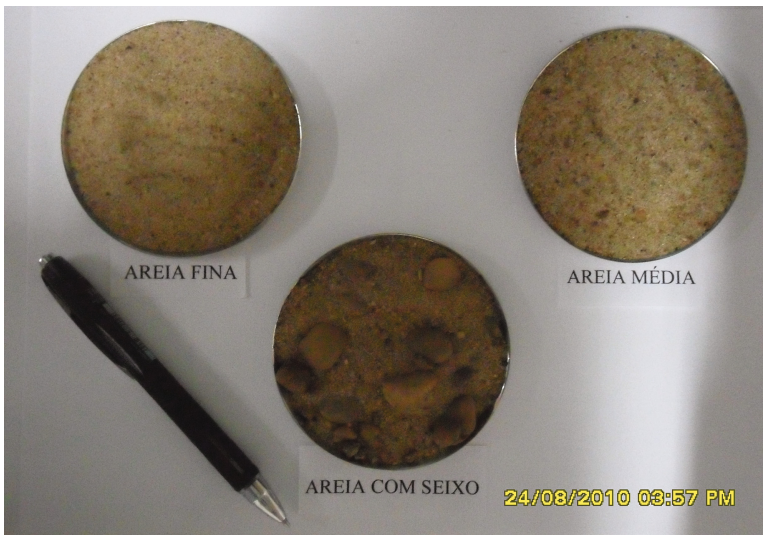

Fig. 19. Sands collected on the banks of the São Francisco River in Itacarambi/MG. 


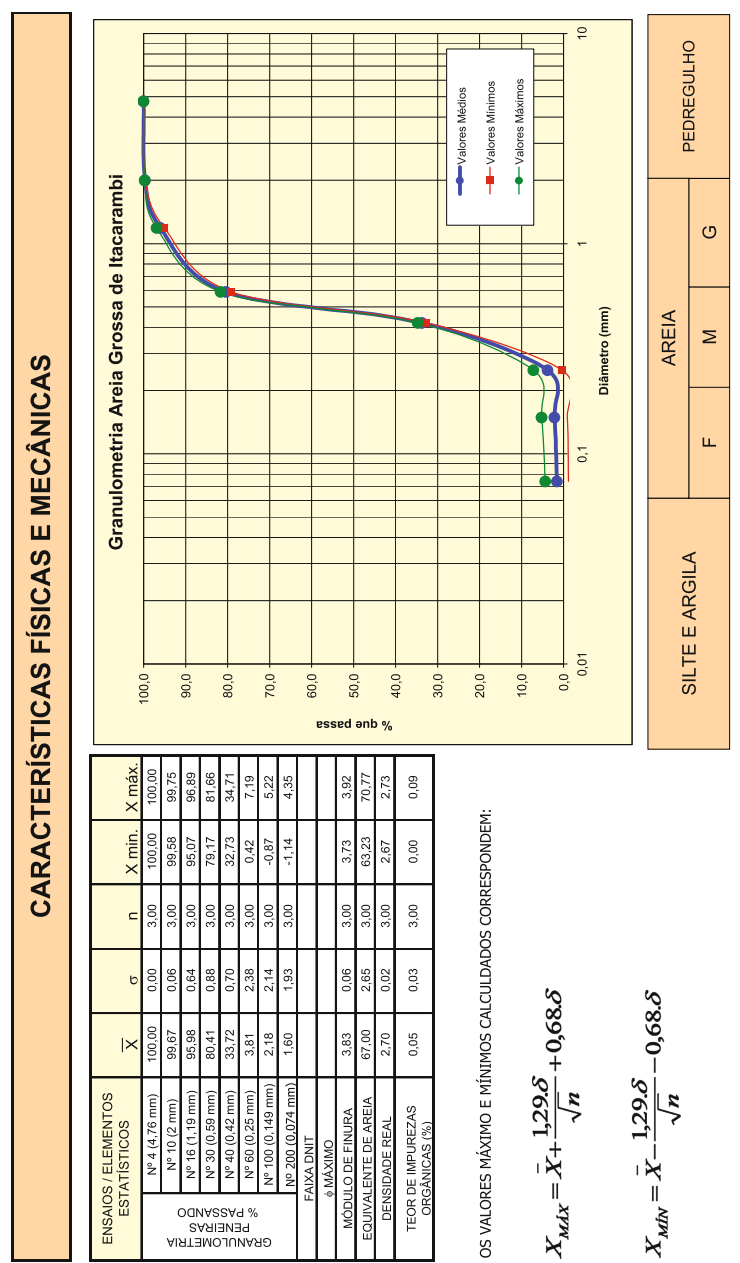

Fig. 20. Study summary for the dredged coarse sand of the São Francisco River in the municipality of Itacarambi.

Figure 20 shows the summary of the study to the coarse sand dredged from the São Francisco River in the municipality of Itacarambi. It is observed that the sand in terms of the equivalent material has $67 \%$ with low organic impurities.

\section{Analysis and Conclusions}

This article aims to present some of the results of geotechnical studies carried out in the area and materials collected in the BR 135 in the section between the municipalities of Manga and Itacarambi in the state of Minas Gerais. With support for the implementation of field work and laboratory and analyzes, we conclude that: 
(a) the area is covered by soils with visual tactile characteristics similar to the predominance of latosols sandy yellow/red;

(b) in terms of granulometric the soil is predominantly sandy in the center of the track to be paved, presents itself as not liquid and not plastic; Sand equivalency equal to 33\%; Group Index equal to zero; The predominant soil A-2-4 (gravel or silty or clayey sands) the classification TRB (HRB); optimum moisture content in the normal energy equal to 8\%; ISC (CBR) 18\%; Expansion of the compacted material after $96 \mathrm{~h}$ of immersion of $0.86 \%$; apparent density of $1,77 \mathrm{~g} / \mathrm{cm}^{3}$; natural moisture of $1.86 \%$;

(c) In the case of rocky material, it was found that there is a high occurrence of carbonate rocks in the region. This material is exploited and used as building material, especially on pavements and as aggregates for concrete (Gravel 1, 2 and Gravel Gravel powder);

(d) by mixing the soil in a field with gravel in a $20 \%$ to $30 \%$ Gravel, being respectively $80 \%$ and $70 \%$ soil, it was found that the normal power sample with $20 \%$ gravel has a specific mass dried and optimum moisture, respectively $2,03 \mathrm{~g} / \mathrm{cm}^{3}$ and $8.70 \%$ with $22.30 \%$ CBR. Already the sample with $30 \%$ of crushed stone features $2.14 \mathrm{~g} / \mathrm{cm}^{3}$ and $7.49 \%$ of optimum moisture and CBR of $30 \%$.

Acknowledgments. The Reforsolo Engenharia Ltda, National Department of Transport Infrastructure (DNIT), Department of Engineering and Construction of the Brazilian Army (DEC), Centre of Excellence in Transportation Engineering (CENTRAN.); Catholic University of Brasilia (UCB), IesPlan and UniCEUB with important contributions that made possible the realization of this work.

\section{References}

DNIT (DNER-ES 301/97): Pavimentação - sub-base estabilizada granulometricamente DNIT (DNER-ES 303/97): Pavimentação - base estabilizada granulometricamente MEDRADO, Wallen Alexandre. Caracterização Geotécnica de Solo da Região Norte de Minas Gerais para Aplicação em Obras Rodoviárias. Dissertação de Mestrado. UFOP (2009) NORMAS Diversas ABNT-NBR/DNIT para ensaios em laboratório NORMAS Diversas ABNT-NBR/DNIT para trabalhos de campo 